\title{
Modelling and Environmental/Economic Power Dispatch of MicroGrid Using MultiObjective Genetic Algorithm Optimization
}

\author{
Faisal A. Mohamed ${ }^{1}$ and Heikki N. Koivo ${ }^{2}$ \\ ${ }_{1}^{1}$ Department of Electrical Engineering, Omar Al-Mukhtar Universityhe University, \\ ${ }^{2}$ Department of Automation and Systems Technology, Aalto University, \\ ${ }^{1}$ Libya \\ 2Finland
}

\section{Introduction}

MultiObjective (MO) optimization has a very wide range of successful applications in engineering and economics. Such applications can be found in optimal control systems (Liu et al., 2007), and communication (Elmusrati et al., 2007). The MO optimization can be applied to find the optimal solution which is a compromise between multiple and contradicting objectives.

In MO optimization we are more interested in the Pareto optimal set which contains all noninferior solutions. The decision maker can then select the most preferred solution out of the Pareto optimal set.

The weighted sum method to handle MO optimization applied in this paper. Furthermore, the weighted sum is simple and straightforward method to handle MO optimization problems.

The need for more flexible electric systems to cope with changing regulatory and economic scenarios, energy savings and environmental impact is providing impetus to the development of MicroGrids (MG), which are predicted to play an increasing role of the future power systems (Hernandez-Aramburo et al., 2005). One of the important applications of the MG units is the utilization of small-modular residential or commercial units for onsite service. The MG units can be chosen so that they satisfy the customer load demand at compromise cost and emissions all the time. Solving the environmental economic problem in the power generation has received considerable attention. An excellent overview on commonly used environmental economic algorithms can be found in (Talaq et al., 1994). The environmental economic problems have been effectively solved by multiobjective evolutionary in (Abido, 2003) and fuzzy satisfaction-maximizing approach (Huang et al., 1997).

Several strategies have been reported in the literature related to the operation costs as well as minimizing emissions of MG. In (Hernandez-Aramburo et al., 2005) the optimization is aimed at reducing the fuel consumption rate of the system while constraining it to fulfil the local energy demand (both electrical and thermal) and provide a certain minimum reserve 
power. In (Hernandez-Aramburo et al., 2005) and (Mohamed \& Koivo, 2010), the problem is treated as a single objective problem. This formulation, however, has a severe difficulty in finding the best trade-off relations between cost and emission. In (Mohamed \& Koivo, 2007) the problem is handled as a multiobjective optimization problem without considering the sold and purchased power.

The algorithm in (Mohamed \& Koivo, 2008) is modified in this chapter; the modification is to optimize the MG choices to minimize the total operating cost. Based on sold power produced by Wind turbine and Photovoltaic Cell, then the algorithm determines the optimal selection of power required to meet the electrical load demand in the most economical and environmental fashion.

Furthermore, the algorithm consists of determining at each iteration the optimal use of the natural resources available, such as wind speed, temperature, and irradiation as they are the inputs to windturbine, and photovoltaic cell, respectively. If the produced power from the wind turbine and the photovoltaic cell is less than the load demand then the algorithm goes to the next stage which is the use of the other alternative sources according to the load and the objective function of each one.

This chapter assumes the MG is seeking to minimize total operating costs. MicroGrids could operate independently of the uppergrid, but they are usually assumed to be connected, through power electronics, to the uppergrid. The MG in this paper is assumed to be interconnected to the uppergird, and can purchase some power from utility providers when the production of the MG is insufficient to meet the load demand. There is a daily income to the MG when the generated power exceeds the load demand.

The second objective of this chapter deals with solving an optimization problem using several scenarios to explore the benefits of having optimal management of the MG. The exploration is based on the minimization of running costs and is extended to cover a load demand scenario in the MG. Furthermore, income also considered from sold power of WT and PV. Switching one load is considered in this paper. It will be shown that by developing a good system model, we can use optimization to solve the cost optimization problem accurately and efficiently. The result obtained is compared with the results obtained from (Mohamed \& Koivo, 2009).

\section{System description}

The MG architecture studied is shown in Fig 1. It consists of a group of radial feeders, which could be part of a distribution system. There is a single point of connection to the utility called point of common coupling (PCC). The feeders 1 and 2 have sensitive loads which should be supplied during the events. The feeders also have the microsources consisting of a photovoltaic (PV), a wind turbine (WT), a fuel cell (FC), a microturbine (MT), and a diesel generator (DG). The third feeder has only traditional loads. A static switch (SD) is used to island the feeders 1 and 2 from the utility when events requiring it happen. The fuel input is needed only for the DG, FC, and MT as the fuel for the WT and PV comes from nature. To serve the load demand, electrical power can be produced either directly by PV, WT, DG, MT, or FC. The diesel oil is a fuel input to the DG, whereas natural gas is a fuel input to a fuel processor to produce hydrogen for the FC. The gas is also the input to the MT. Each component of the MG system is modeled separately based on its characteristics and constraints. The characteristics of some equipment like wind turbines and diesel generators are available from manufacturers. 


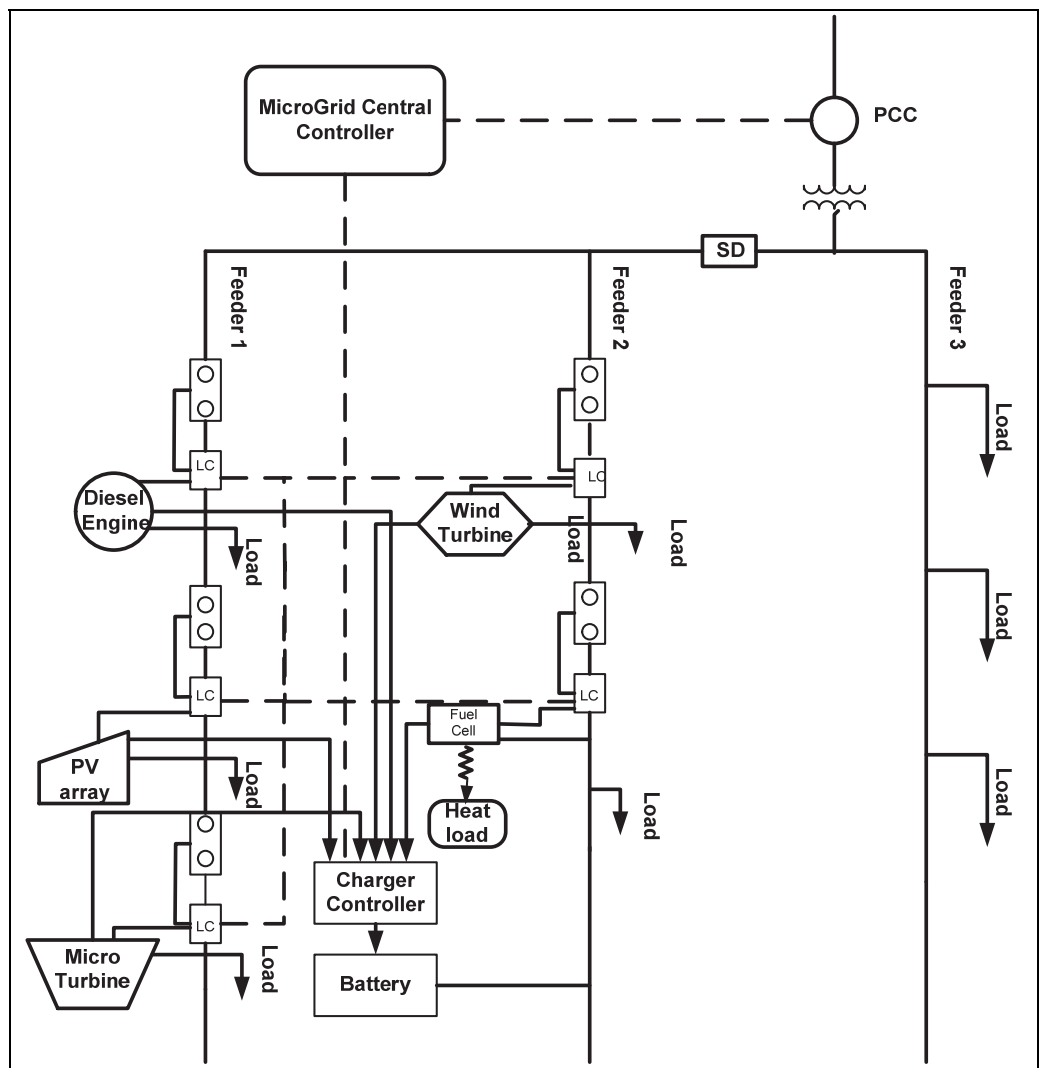

Fig. 1. MicroGrid Architecture.

\section{Optimization model}

The power optimization model is formulated as follows. The output of this model is the optimal configuration of a MG taking into account the technical performance of supply options, locally available energy resources, load demand characteristics, environmental costs, start up cost, daily purchased-sold power tariffs, and operating and maintenance costs.

Figure 2. illustrates the optimization model, when its inputs are:

- Power demand by the load.

- Data about locally available energy resources: These include wind speed (m/s) Figure 3 , temperature $\left(\mathrm{C}^{\circ}\right)$ Figure 4 , solar irradiation data $\left(\mathrm{W} / \mathrm{m}^{2}\right)$ Figure 5 , as well as cost of fuels (\$/liter) for the DG and natural gas price for supplying the FC and MT $(\$ / \mathrm{kW})$.

- Daily purchased and sold power tariffs in $(\mathrm{kWh})$.

- Start up costs in $(\$ / \mathrm{h})$.

- Technical and economic performance of supply options: These characteristics include, for example, rated power for PV, power curve for WT, fuel consumption characteristics DG and FC. 
- Operating and maintenance costs and emission factors: Operating and maintenance costs must be given $(\$ / \mathrm{h})$ for all generators; emission factors must be given in $\mathrm{kg} / \mathrm{h}$ for DG, FC, and MT.

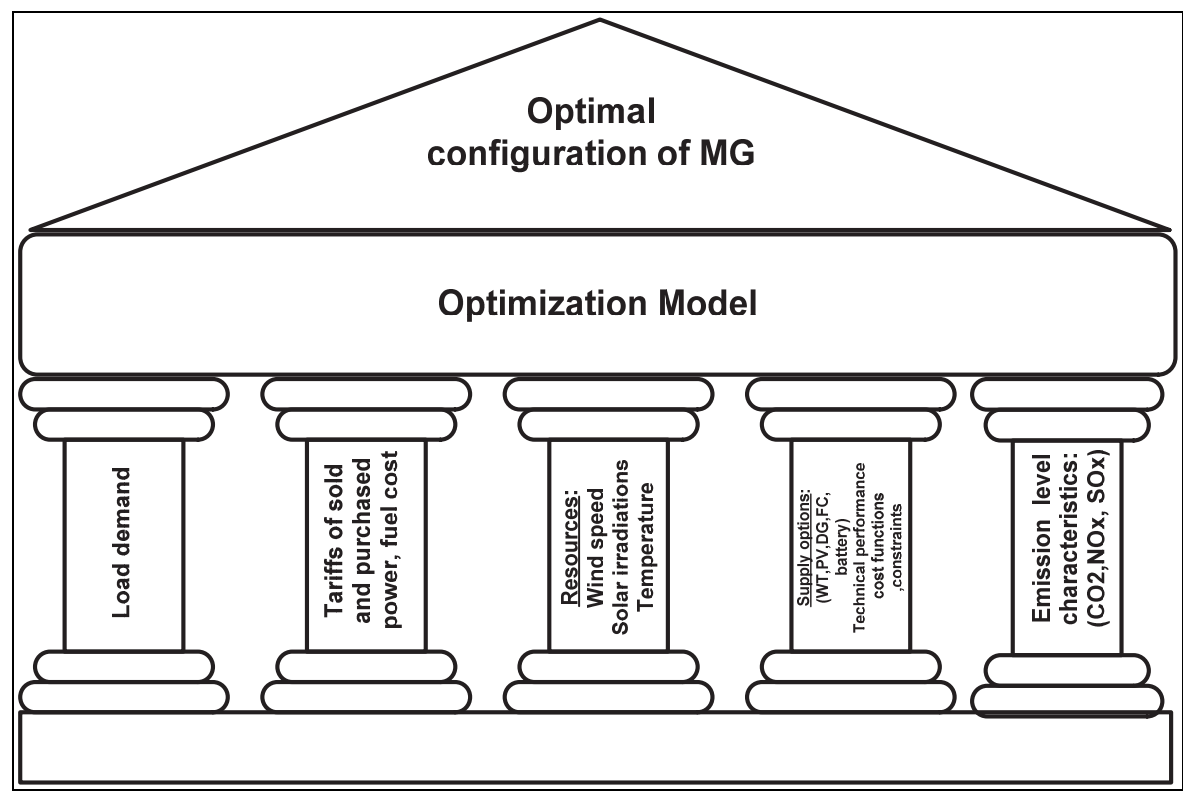

Fig. 2. The Optimization Model.

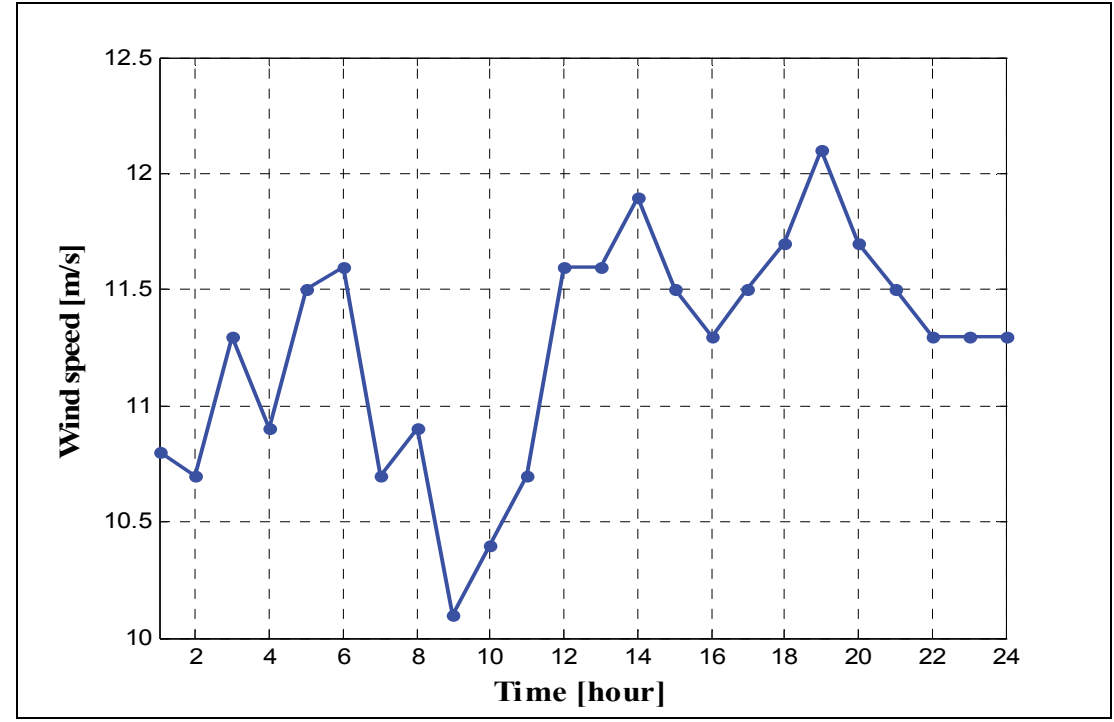

Fig. 3. The input wind speed as used in the model. 


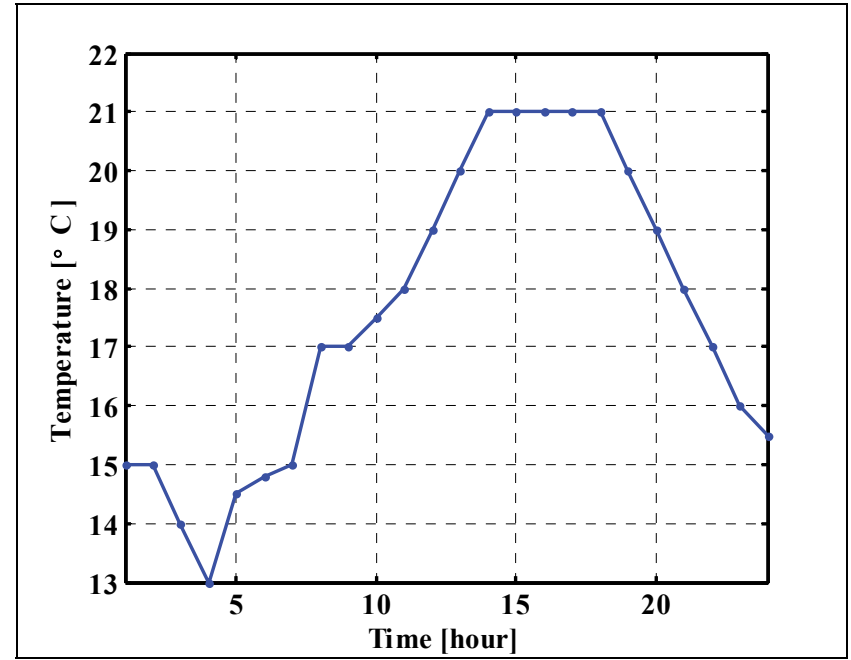

Fig. 4. The input temperature data as used in the model.

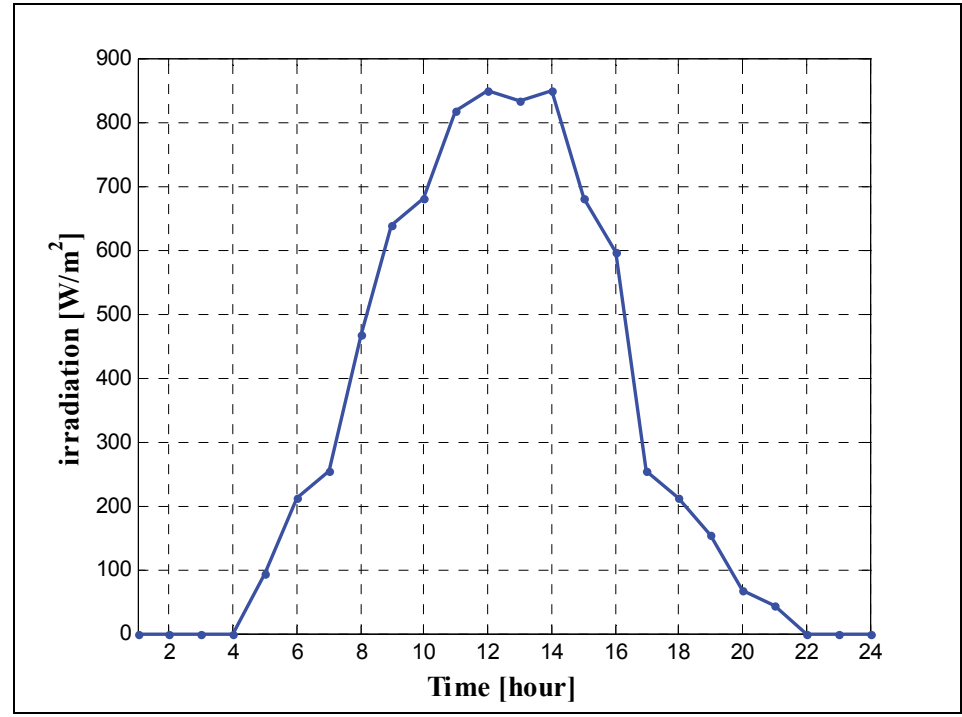

Fig. 5. The input irradiation data as used in the model.

\section{Optimization model}

\subsection{Wind turbine}

To model the wind turbine, several important factors should be known. They are the availability of the wind and the wind turbine power curve. The following is the model used to calculate the output power generated by the wind turbine generator as a function of the wind velocity (Chedid et al., 1998): 


$$
\begin{cases}P_{W T}=0, & V_{a c}<V_{c i} \\ P_{W T}=a V_{a c}^{2}+b V_{a c}+c, & V_{c i} \leq V_{a c}<V_{r} \\ P_{W T, r}=130, & V_{r} \leq V_{a c}>V_{c o}\end{cases}
$$

where $P_{W T, r}, V_{c i}$ and $V_{c o}$ are the rated power, cut-in and cut-out wind speed respectively. Furthermore $V_{r}$, and $\mathrm{V}$ are the rated, and actual wind speed. Constants $\mathbf{a}, \mathbf{b}$, and $\mathbf{c}$ depend on the type of the WT.

We assume AIR403 wind turbine model in this paper. According to the data from the manufacturer, the turbine output $\mathbf{P}_{\mathbf{W T}, \mathbf{r}}$ is roughly $130 \mathrm{~W}$ if the wind speed is greater than approximately $18 \mathrm{~m} / \mathrm{s}$.

In Fig 6. we model the wind turbine power curve according to equation 1, with the actual power curve obtained from the owner's manual. The parameters used to model the power curve are as follows:

$\mathrm{a}=3.4 ; \mathrm{b}=-12 ; \mathrm{c}=9.2 ; \mathbf{P}_{\mathrm{WT}, \mathrm{r}}=130 \mathrm{watt} ; \mathbf{V}_{\mathbf{c i}}=3.5 \mathrm{~m} / \mathrm{s} ; \mathbf{V}_{\mathbf{c o}}=18 \mathrm{~m} / \mathrm{s} ; \mathbf{V}_{\mathbf{r}}=17.5 \mathrm{~m} / \mathrm{s}$.

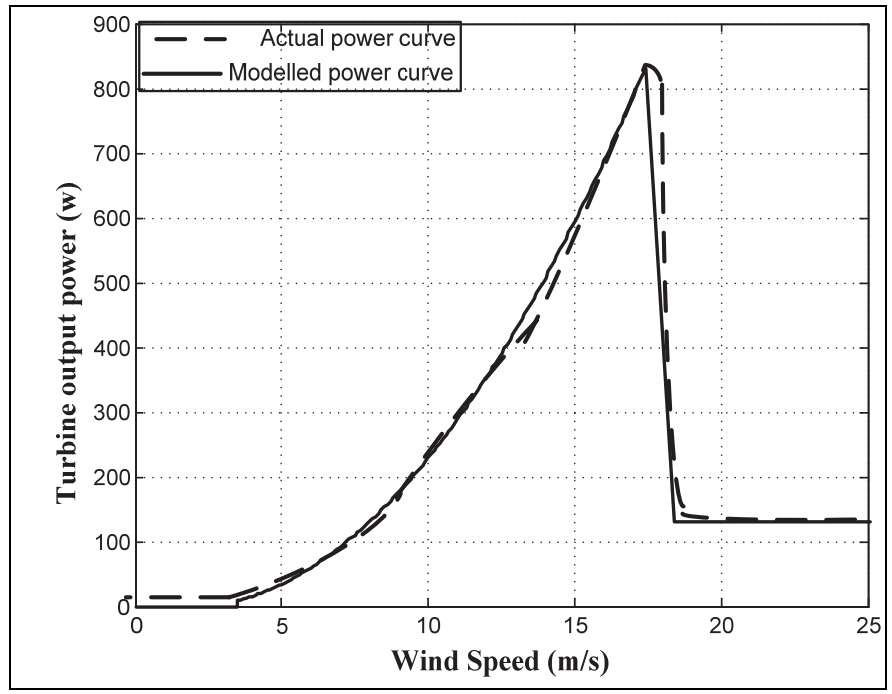

Fig. 6. The actual and modeled power curve of AIR403.

\subsection{Photovoltaic}

Photovoltaic generations are systems which convert the sunlight directly to electricity. The characteristics of the PV in operating conditions that differ from the standard condition $\left(1000 \mathrm{~W} / \mathrm{m}^{2}, 25 \mathrm{C}^{\circ}\right.$ cell temperature), the effect of solar irradiation and ambient temperature on PV characteristics are modeled. The influence of solar intensity is modeled by considering the power output of the module to be proportional to the irradiance (Gavanidou \& Bakirtzis 1992), (Lasnier \& Ang 1990). The PV Modules are treated at Standard Test Condition (STC). The output power of the module can be calculated using:

$$
P_{P V}=P_{S T C} \frac{G_{I N G}}{G_{S T C}}\left[1+k\left(T_{c}-T_{r}\right)\right]
$$


where:

$P_{P V} \quad$ The output power of the module at Irradiance $G_{I N G}$,

$\mathrm{P}_{\mathrm{STC}} \quad$ The Module maximum power at Standard Test Condition (STC),

GING Incident Irradiance,

GSTC Irradiance at STC $1000\left(\mathrm{~W} / \mathrm{m}^{2}\right.$,

$\mathrm{k}$ Temperature coefficient of power,

$\mathrm{T}_{\mathrm{c}} \quad$ The cell temperature,

$\mathrm{T}_{\mathrm{r}} \quad$ The reference temperature.

We assume that SOLAREX MSX-83 modules are used in this paper. Their output characteristics are: peak power $=83 \mathrm{~W}$, voltage at peak power $=17.1 \mathrm{~V}$, current at peak power $=4.84 \mathrm{~A}$, short circuit current $=5.27 \mathrm{~A}$, and open circuit voltage $=21.2 \mathrm{~V}$ at STC.

\subsection{Diesel generator costs}

Diesel engines are the most common type of MG technology in use today. The traditional roles of diesel generation have been the provision of stand-by power and peak shaving. The fuel cost of a power system can be expressed mainly as a function of its real power output and can be modeled by a quadratic polynomial (Wood \& Wollenberg 1996. The total \$/h DG fuel cost $\mathbf{F}_{\mathbf{D G}, \mathrm{i}}$ can be expressed as:

$$
F_{D G, i}=\sum_{i=1}^{N}\left(d_{i}+e_{i} P_{D G, i}+f_{i} P_{D G, i}^{2}\right)
$$

where $\mathbf{N}$ is the number of generators, $\mathbf{d}_{\mathbf{i}}, \mathbf{e}_{\mathbf{i}}$, and $\mathbf{f}_{\mathbf{i}}$ are the coefficients of the generator, $\mathbf{P}_{\mathrm{DG}, \mathbf{i}}$ $\mathbf{i}=1,2, \ldots, \mathbf{N}$ is the diesel generator $\mathbf{i}$ output power $(\mathrm{kW})$, assumed to be numerically known. Typically, the constants $\mathbf{d}_{\mathbf{i}}, \mathbf{e}_{\mathbf{i}}$, and $\mathbf{f}_{\mathbf{i}}$ are given by the manufacturer. For example, diesel fuel consumption data of a 6-kW diesel generator set (Cummins Power) model DNAC $50 \mathrm{~Hz}$ is available in $\mathrm{L} / \mathrm{h}$ at $1 / 4,1 / 2,3 / 4$ and full loads. From the data sheet the parameters in eq (3) are: $\mathbf{d}_{\mathbf{i}}=0.4333, \mathbf{e}_{\mathbf{i}}=0.2333$, and $\mathbf{f}_{\mathbf{i}}=0.0074$. Figure 7 shows the fuel consumption as function of power of the DNAC $50 \mathrm{~Hz}$ diesel engine.

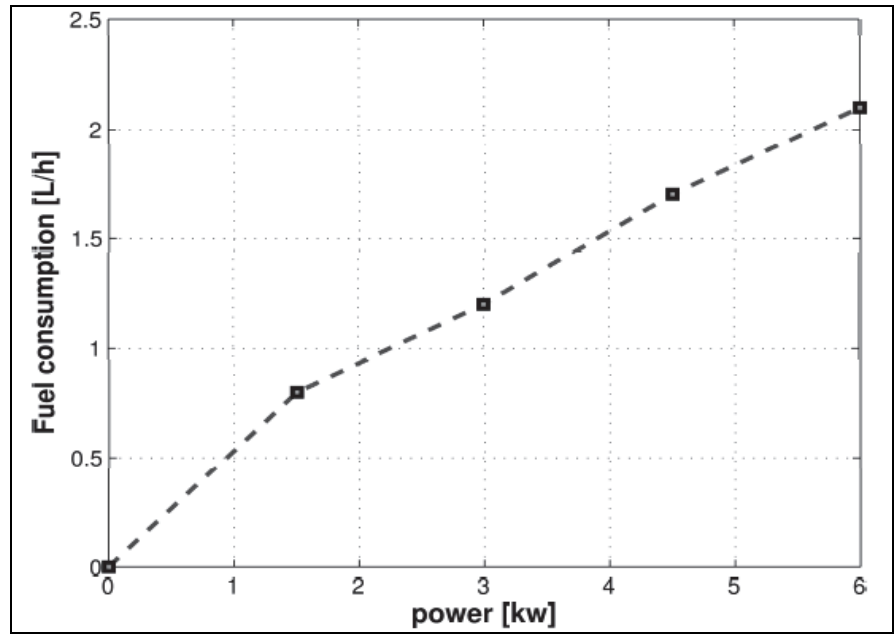

Fig. 7. Fuel consumption of DNAC $50 \mathrm{~Hz}$ diesel engine. 


\subsection{Fuel cell cost}

Fuel cells work by combining hydrogen with oxygen to produce electricity, heat, and water. DC current and heat are produced by a chemical reaction rather than by a mechanical process driven by combustion. Fuel cells can operate as long as fuel is being supplied, as opposed to the fixed supply of chemical energy in a battery.

The efficiency of the FC depends on the operating point, and it refers to the ratio of the stack output power to the input energy content in the natural gas. It is normally calculated as the ratio of the actual operating voltage of a single cell to the reversible potential $(1.482 \mathrm{~V})$ (Barbir \& Gomez, 1996). The overall unit efficiency is the efficiency of the entire system including auxiliary devices.

We assume the typical efficiency curves of the Protone Exchange Membrane (PEM) fuel cell including the cell and the overall efficiencies (Barbir \& Gomez, 1996). The efficiency of any fuel cell is the ratio between the electrical power output and the fuel input, both of which must be in the same units (W), (Azmy \& Erlic, 2005):

The fuel cost for the fuel cell is calculated as follows:

$$
F_{F C, i}=C_{n l} \sum_{J} \frac{P_{J}}{\eta_{J}}
$$

where

$\mathrm{C}_{\mathrm{nl}} \quad$ the natural gas price to supply the fuel cell $(\$ / \mathrm{kWh})$,

$\mathbf{P}_{\mathbf{J}} \quad$ the net electrical power produced at interval \$J $\$$,

$\eta_{J} \quad$ the cell efficiency at interval J.

To model the technical performance of a PEM fuel cell (Barbir \& Gomez, 1996), a typical efficiency curve is used to develop the cell efficiency as a function of the electrical power and used in equation (4).

\subsection{Microturbine cost}

Microturbines use a simple design with few moving parts to improve reliability and reduce maintenance costs. Microturbine models are similar to those of fuel cells (Campanari \& Macchi,2004). However, the parameters and curves are modified to properly describe the performance of the MT unit. From a typical electrical and thermal efficiency curves of a 25 kW Capstone- C30 microturbine (Yinger, 2001) we obtain the efficiency as function of the generated power. The total efficiency of a microturbine can be written as:

$$
\eta_{J}=\frac{P_{e l}+P_{t h, r e c}}{m_{f} L H V_{f}}
$$

where

$P_{e l} \quad$ the net electrical output power $(\mathrm{kW})$,

$P_{\text {th }, \text { rec }}$ the thermal power recovered $(\mathrm{kW})$,

$L H V_{f}$ the fuel lower heating rate $(\mathrm{kJ} / \mathrm{kgf})$,

$m_{f} \quad$ the mass flow rate of the fuel $(\mathrm{kg} / \mathrm{s})$.

Unlike the fuel cell, the efficiency of the MT increases with the increase of the supplied power. The MT fuel cost is as follows: 


$$
C_{M T}=C_{n l} \sum_{J} \frac{P_{J}}{\eta_{J}}
$$

where

$\mathbf{C}_{\mathbf{n l}}$ is the natural gas price to supply the MT,

$\mathbf{P}_{\mathbf{J}}$ is the net electrical power produced at interval $\mathbf{J}$,

$\eta_{J}$ is the cell efficiency at interval $\mathbf{J}$.

Since power required by our assumed MG is much lower than the level in (Yinger, 2001), the curves of this MT are rescaled to be suitable for a unit with a $4 \mathrm{~kW}$ rating. These curves are used to derive the electrical efficiency and power as functions of the electrical power to be used in the economic model of the MT.

\subsection{Battery storage}

Battery banks are electrochemical devices that store energy from other AC or DC sources for later use. The power from the battery is needed whenever the microsources are insufficient to supply the load, or when both the microsources and the main grid fail to meet the total load demand. On the other hand, the energy is stored whenever the supply from the microsources exceeds the load demand.

The following assumptions are used to model the battery bank: the charge and discharge current is limited to $10 \%$ of battery $\mathrm{AH}$ capacity (the storage capacity of a battery is measured in terms of its ampere-hour (AH) capacity) (Chedid \& Rahman, 1997) and (Manisaet, 2004); the round- trip efficiency is $95 \%$.

When determining the state of charge for an energy storage device, two constraint equations must be satisfied at all times: First, because it is impossible for an energy storage device to contain negative energy, the maximum state of charge $\left(\mathbf{S O C}_{\max }\right)$ and the minimum state of charge $\left(\mathbf{S O C}_{\min }\right)$ of the battery are $100 \%$ and $20 \%$ of its AH capacity, respectively.

The constraints that represent the maximum allowable charge and discharge current to be less than $10 \%$ of battery $\mathrm{AH}$ capacity are shown in the following equations, respectively.

$$
\begin{aligned}
& P_{+} \leq\left(0.1 \times V_{\text {sys }} \times U_{\text {batt }}\right) / \Delta_{t} \\
& P_{-} \leq\left(0.1 \times V_{\text {sys }} \times U_{\text {batt }}\right) / \Delta_{t}
\end{aligned}
$$

where the parameter $\mathbf{V}_{\text {sys }}$ is the system voltage at the DC bus, $\Delta_{t}$ is the time in hours, and the parameter $\mathbf{U}_{\text {batt }}$ is the battery capacity in AH. The state of charge (SOC) of the battery can be obtained by monitoring the charge/discharge power of the battery, as shown in eq.(9).

$$
S O C=S O C_{\max }-P_{-}+P_{+}
$$

It is important that the SOC of the battery prevents the battery from overcharging or undercharging. The associated constraints can be formulated by comparing the battery SOC in any hour i with the battery $\mathbf{S O C}_{\min }$ and the battery $\mathbf{S O C}_{\max }$, as shown in eq(10).

This research assumes that $\mathbf{S O C}_{\min }$ and $\mathbf{S O C}_{\max }$ equal $20 \%$ and $100 \%$ of the battery $\mathrm{AH}$ capacity, respectively. It is also assumed that the initial SOC of the battery is $100 \%$ at the beginning of the simulation. 
The constraints on battery SOC are:

$$
S O C_{\min } \leq S O C \leq S O C_{\max }
$$

Finally, in order for the system with battery to be sustained over a long period of time, the battery SOC at the end must be greater than a given percentage of its $\mathbf{S O C}_{\max }$. This study assumes $90 \%$.

\section{Proposed objective function}

The major concern in the design of an electrical system that utilizes MG sources is the accurate selection of output power that can economically satisfy the load demand, while minimizing the emission. Hence the system components are found subject to:

1. Minimize the operation cost $(\$ / \mathrm{h})$.

2. Minimize the emissions $(\mathrm{kg} / \mathrm{h})$.

3. Ensure that the load is served according to the constraints.

\subsection{Operating cost}

As shown in Fig.1, the main utility balances the difference between the load demand and the generated output power from microsources. Therefore there is a cost to be paid for the purchased power whenever the generated power is insufficient to cover the load demand. On the other hand, there is income because of sold power when the power generated is higher than the load demand but the price of the sold power is lower than the purchased power tariff. It is possible that there will be no sold power at all. To model the purchased and sold power, the cost function takes the form

$$
C F(\boldsymbol{P})=\sum_{i=1}^{N}\left(C_{i} F_{i}\left(P_{i}\right)+O M_{i}\left(P_{i}\right)+S T C_{i}+D C P E_{i}-I P S E_{i}\right)
$$

$C F(\boldsymbol{P})$ represents the operating costs in $\$ / \mathrm{h}, C_{i}$ fuel costs of the generating unit $i$ in $\$ / 1$ for the DG, natural gas price for supplying the FC and MT $(\$ / \mathrm{kWh}), F_{i}\left(P_{i}\right)$ fuel consumption rate of a generator unit $i, O M_{i}\left(P_{i}\right)$ Operation and maintenance cost of the generating unit $i$ in $\$ / \mathrm{h}, P_{i}$ decision variables, representing the real power output from generating unit $i$ in $\mathrm{kW}$ and defined as: $P_{i}=P_{F C}$ or $P_{M T}$ or $P_{D G}, \boldsymbol{P}$ is the vector of the generators active power and is defined as: $\boldsymbol{P}=\left[P_{1}, P_{2}, \ldots, P_{N}\right]^{\prime}, N$ is the total number of generating units. where $S T C_{i}$ is the start-up costs of the unit generator $i \$ / \mathrm{h}$. The start-up cost in any given time interval can be represented by an exponential cost curve:

$$
S T C_{i}=\sigma_{i}+\delta_{i}\left[1-\exp \left(\frac{-T_{o f f, i}}{\tau_{i}}\right)\right]
$$

The start-up cost depends on the time the unit has been off prior to a start up.

where, $\sigma_{i}$ is the hot start-up cost, $\delta_{i}$ the cold start-up cost, $\tau_{i}$ the unit cooling time constant and $T_{\text {off }, i}$ is the time a unit has been off.

$D C P E_{i}$ is the daily purchased electricity of unit $i$ if the load demand exceeds the generated power in $\$ / \mathrm{h}$. IPSE $E_{i}$ is the daily income for sold electricity of unit $i$ if the output generated 
power exceeds the load demand in $\$ / h$. the expression for $D C P E_{i}$ and $I P S E_{i}$ can be written as

$$
\begin{aligned}
& D C P E_{i}=C_{p} \times \max \left(P_{L}-P_{i}, 0\right) \\
& I P S E_{i}=C_{s} \times \max \left(P_{i}-P_{L}, 0\right)
\end{aligned}
$$

where, $C_{p}$ and $C_{s}$ are the tariffs of the purchased and sold power respectively in $(\$ / \mathrm{kWh})$. System Constraints:

Power balance constraints: To meet the active power balance, an equality constraint is imposed

$$
\sum_{i=1}^{N} P_{i}=P_{L}-P_{P V}-P_{W T}-P_{b a t t}
$$

where $P_{L}$ is the total power demanded in $\mathrm{kW}, P_{P V}$ the output power of the photovoltaic cell in $\mathrm{kW}, P_{W T}$ the output power of the wind turbine in $\mathrm{kW}$,

$P_{b a t t}$ the output power of the battery in $\mathrm{kW}$.

Generation capacity constraints: For stable operation, real power output of each generator is restricted by lower and upper limits as follows:

$$
P_{i}^{\min } \leq P_{i} \leq P_{i}^{\max } \quad \forall_{i}=1, \ldots, N
$$

where, $P_{i}^{\min }$ is the minimum operating power of unit $i$ and $P_{i}^{\max }$ the maximum operating power of unit $i$.

Each generating unit has a minimum up/down time limit (MUT/MDT). Once the generating unit is switched on, it has to operate continuously for a certain minimum time before switching it off again. On the other hand, a certain stop time has to be terminated before starting the unit. The violation of such constraints can cause shortness in the life time of the unit. These constraints are formulated as continuous run/stop time constraints as follows (Abido, 2003).

$$
\begin{aligned}
& \left(T_{t-1, i}^{o n}-M U T_{i}\right)\left(u_{t-1, i}-u_{t, i}\right) \geq 0 \\
& \left(T_{t-1, i}^{o f f}-M D T_{i}\right)\left(u_{t, i}-u_{t-1, i}\right) \geq 0
\end{aligned}
$$

$T_{t-1, i}^{\text {off }} / T_{t-1, i}^{o n}$ represent the unit $i$ off/on time, at time $t-1$, while $u_{t-1, i}$ denotes the unit off/on $[0,1]$ status.

Finally the number of starts and stops $\left(\varepsilon_{\text {start-stop }}\right)$ should not exceed a certain number $\left(N_{\max }\right)$.

$$
\varepsilon_{\text {start-stop }} \leq N_{\max }
$$

The operating and maintenance costs $\mathrm{OM}$ are assumed to be proportional with the produced energy, where the proportionally constant is $K_{O M_{i}}$ for unit $i$.

$$
O M=\sum_{i=1}^{N} K_{O M_{i}} P_{i}
$$


The values of $K_{O M_{i}}$ for different generation units are as follows : where,

$$
\begin{aligned}
& K_{O M_{1}}=K_{O M}(D G)=0.01258 \$ / \mathrm{kWh} . \\
& K_{O M_{2}}=K_{O M}(F C)=0.00419 \$ / \mathrm{kWh} . \\
& K_{O M_{2}}=K_{O M}(M T)=0.00587 \$ / \mathrm{kWh} .
\end{aligned}
$$

\subsection{Emission level}

The atmospheric pollutants such as sulphur oxides $\mathrm{SO}_{2}$, carbon oxides $\mathrm{CO}_{2}$, and nitrogen oxides NOx caused by fossil-fueled thermal units can be modeled separately. The total $\mathrm{kg} / \mathrm{h}$ emission of these pollutants can be expressed as (Morgantown, 2001):

$$
E(\boldsymbol{P})=\sum_{i=1}^{N} 10^{-2}\left(\alpha_{i}+\beta_{i} P_{i}+\gamma_{i} P_{i}\right)+\zeta_{i} \exp \left(\lambda_{i} P_{i}\right)
$$

where $\alpha_{i}, \beta_{i}, \gamma_{i}, \zeta_{i}$, and $\lambda_{i}$ are nonnegative coefficients of the $i$ th generator emission characteristics.

For the emission model introduced in (Talaq et al., 1994) and (Morgantown, 2001), we propose to evaluate the parameters $\alpha_{i}, \beta_{i}, \gamma_{i}, \zeta_{i}$, and $\lambda_{i}$ using the data available in (Orero \& Irving, 1997) Thus, the emission per day for the DG, FC, and MT is estimated, and the characteristics of each generator will be detached accordingly.

\section{Implementation of the algorithm}

The following items summarize the key characteristics of the proposed algorithm:

- Power output of WT is calculated according to power the relation between the wind speed and the output power.

- Power output of PV is calculated according to the effect of the temperature and the solar radiation that are different from the standard test condition.

- We assume that the WT and PV deliver free cost power in terms of running as well being emission free. Furthermore, their output power is treated as a negative load, determine the different between the actual load and WT and PV output power. If the output from PV and WT is greater than the load, the excess power is directed to charge the battery.

- The power from the battery is needed whenever the PV and WT are insufficient to serve the load. Meanwhile the charge and discharge of the battery is monitored.

- The net load is calculated if the output from PV and WT is smaller than the total load demand.

- Choose serving the load by other sources (FC or MT or DG) according to the objective functions.

- If the output power is not sufficient then purchase power from the main gird, and if the output power is more than the load demand, sell the exceed power to the main grid. 


\section{Multiobjective genetic algorithm}

There are two common goals in all multiobjective GA implementations. First, to move the population toward the Pareto optimal front; and second, to maintain diversity (either in parameter space or objective space) in the population so that multiple solutions can be developed. GA approaches to multiobjective optimization can be grouped into three categories: approaches that use aggregating functions, non-Pareto based approaches, and Pareto based approaches. The simplest and most obvious approach to multiobjective optimization is to combine the objectives into one aggregating function, and to treat the problem like a single objective optimization problem. Therefore, it is commonly used because of its simplicity and computational efficiency. The weighted sum approach combines objectives using weights.

The weighted sum approach combines $k$ objectives $f_{i}$ using weights, $w_{i}, i=1, \ldots, k$

$$
\text { fitness }=w_{1} f_{2}(\boldsymbol{P})+w_{2} f_{2}(\boldsymbol{P})+\ldots+w_{k} f_{k}(\boldsymbol{P})
$$

The weights are real numbers $w_{i} \geq 0$ and $\mathbf{P}$ as in (11)

\section{Results and discussion}

At first, the optimization model is applied to the load. The load demand varies from $4 \mathrm{~kW}$ to $14 \mathrm{~kW}$. The available power from the PV and the WT are used first. The best results of the cost and emission functions, when optimized individually, are given in Table 1. Convergence of operation cost and emission objectives for both approaches, when the purchased tariff is $0.12 \$ / \mathrm{kWh}$ and the sold tariff $0.07 \$ / \mathrm{kWh}$, is as shown in Figure 8, where faster convergence is achieved.

Figure 9 illustrates the hourly operating costs and emissions. However, the costs and emissions are high when the generators are on and the load is high. Operational cost and emission objectives are optimized individually in order to explore the extreme points of the trade-off surface. The first case is when the cost objective function is optimized and the second when the emission objective function is optimized.

The set of power curve found by the optimization algorithms is shown in Figure 10. The figure confirms that when the load demand is low, the best choice in terms of cost is to use the output power from MT. The second best choice is the use of the fuel cell.

When the load is high at the peak time, all the generators are used to serve the load.

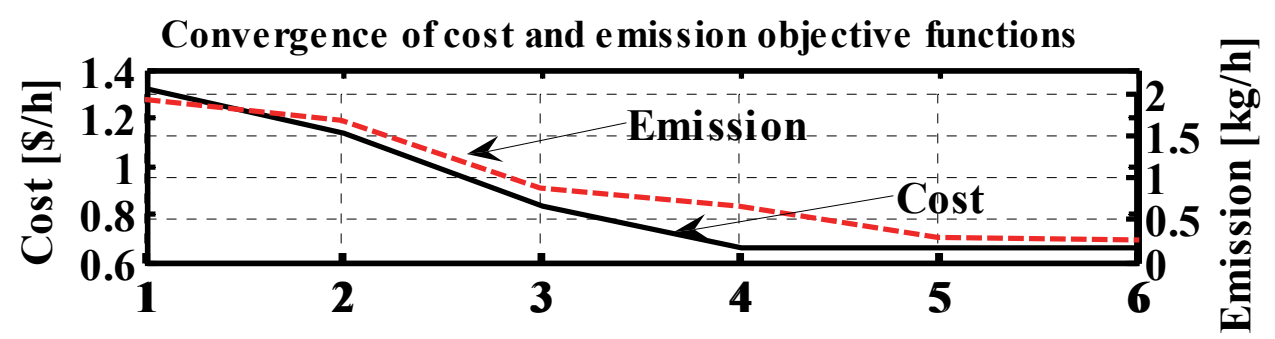

Fig. 8. Convergence of cost and emission objective functions. 


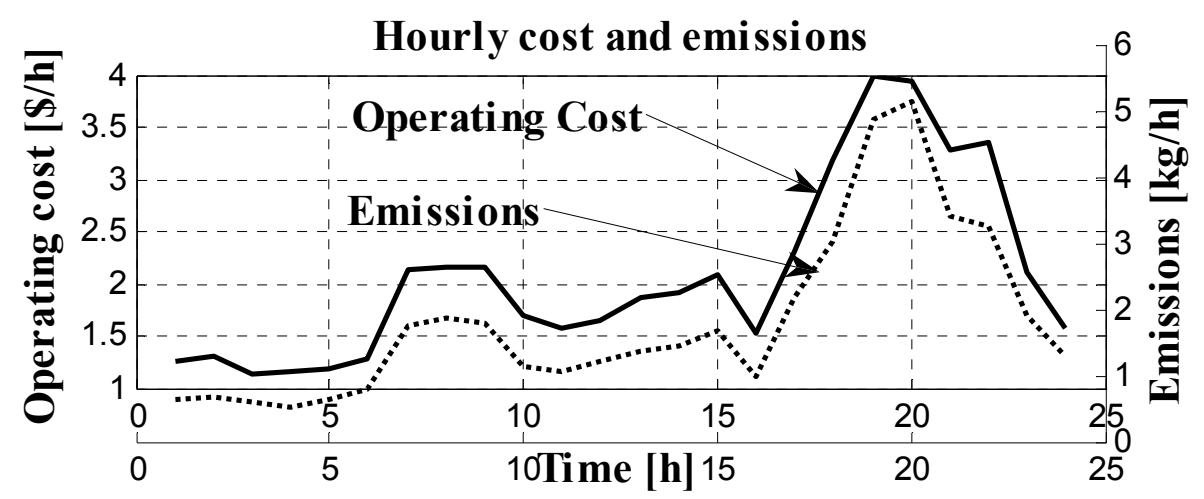

Fig. 9. Hourly operating cost and emission

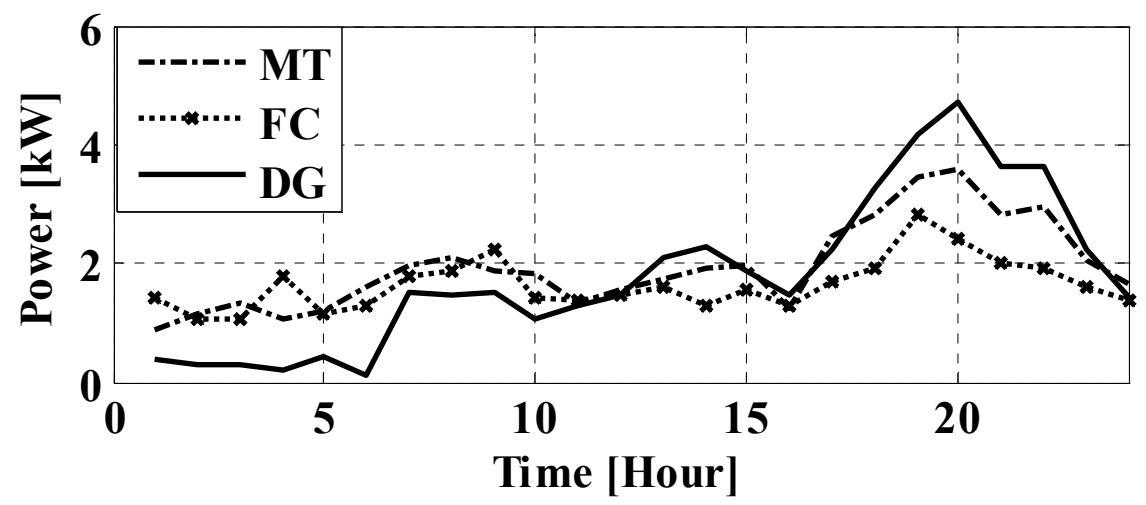

Fig. 10. Power Generation distribution.

\begin{tabular}{||c|c|c|c|c|c|c||}
\hline \hline & $\begin{array}{c}\text { TOTAL } \\
\text { LOAD } \\
(\mathrm{KW} / \mathrm{DAY})\end{array}$ & $\begin{array}{c}\text { TOTAL } \\
\text { EMISSIONS } \\
(\mathrm{KG} / \mathrm{DAY})\end{array}$ & $\begin{array}{c}\text { Total } \\
\text { Costs } \\
\text { (\$/Day) }\end{array}$ & $\begin{array}{c}\text { Optimal } \\
\text { Generation } \\
(\mathrm{kW} / \text { Day })\end{array}$ & $\begin{array}{c}\text { Sold Power } \\
\text { (kW7Day) }\end{array}$ & $\begin{array}{c}\text { Purchased } \\
\text { Power } \\
\text { (kW/Day })\end{array}$ \\
\hline Case 1 & 171.4009 & 127.250 & 86.3466 & 352.8773 & 70.5188 & 14.8635 \\
Case 2 & 171.4009 & 9.6045 & 224.4015 & 31.8217 & 00.0000 & 135.3149 \\
\hline \hline
\end{tabular}

Table 1. The Objective Function when Optimized Individually.

Figure 11 shows the relationship (trade-off curve) of the operating cost and emission objectives of the non-dominated solutions obtained for different purchased and sold tariffs. The operating costs of the non-dominated solutions thus appear to be inversely proportional to their emissions.

Table 2. shows the effect of changing the purchased and sold tariffs on the optimal setting of the MG. There are all together four cases. 


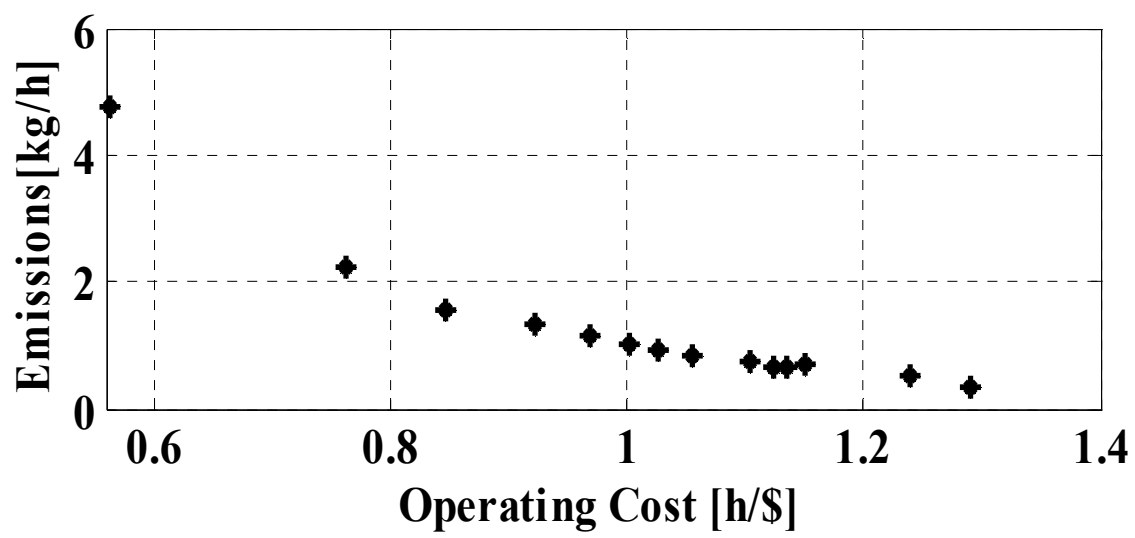

Fig. 11. Trade- off in cost and emission.

\begin{tabular}{||l|c|c|c|c||}
\hline \hline & $\begin{array}{c}\text { TOTAL } \\
\text { LOAD } \\
\text { (KW/DAY }\end{array}$ & $\begin{array}{c}\text { Optimal } \\
\text { Generation } \\
\text { (KW/DAY) }\end{array}$ & $\begin{array}{c}\text { Total } \\
\text { Cost } \\
\text { (\$/Day) }\end{array}$ & $\begin{array}{c}\text { TOTAL } \\
\text { EMISSION } \\
\text { (kg/Day) }\end{array}$ \\
\hline Case 1 & 171.4009 & 88.3430 & 38.8254 & 25.9907 \\
Case 2 & 171.4009 & 117.2192 & 45.1067 & 37.2475 \\
Case 3 & 171.4009 & 110.5423 & 43.8823 & 34.3452 \\
Case 4 & 171.4009 & 110.3820 & 43.9964 & 34.5317 \\
\hline \hline
\end{tabular}

Table 2. The effect of the purchased and sold tariffs on the optimal generation using MOGA.

In case 1 , the effect of the changing the purchased ariffs is studied, when the sold power was $0.04 \$ / \mathrm{kWh}$ and the purchased tariffs were $0.1 \$ / \mathrm{kWh}$, while in Case 2 the value of the purchased tariffs has increased to $0.16 \$ / \mathrm{kWh}$ and the sold was the same as in Case 1 . During changing the purchased tariffs values, it was noticed that when the tariffs were low, it was preferable to buy as much power from the main grid as possible. However, when the tariffs were higher, it was more economic to generate the required power from the MG.

In Cases 3 and 4, the purchase power tariff is kept constant at $0.12 \$ / \mathrm{kWh}$, while the sold tariffs was $0.0 \$ / \mathrm{kWh}$ in case 3 and $0.04 \$ / \mathrm{kWh}$ in case 4 . It is noticeable that, the changing of the sold tariffs has no effect for such a small change. It only reacts if the change is much larger. Table 3. illustrates the cost savings and emission reductions of the MG using different cases and compares them with the proposed technique.

The results obtained using the proposed technique to minimize the total cost and total emissions are compared with some conventional strategies of settings. The first case is when the DG, FC, and MT operate at their rated power for the whole day (Case A). The second is to optimize the cost individually (Case B). The third scenario is to optimize the emissions objective function individually (Case C).

Case A gives higher operating cost and higher emissions which indicates that it is not relevant. The larger generating power, the larger costs and emissions are attained. In the 
Case $\mathrm{B}$, the cost is relatively reduced, while the emissions were increased. In the third case, the cost increased while the emissions decreased and the optimal choice was to purchase more power from the main grid.

For achieving the completeness and checking the effectiveness of the proposed cost function and proposed solution, the problem was treated as single objective optimization problem by a linear combination of the cost and emission objectives as follows (Abido, 2003a) (case D):

$$
\underset{\boldsymbol{P}}{\operatorname{Minimize}} \quad \omega C F(\boldsymbol{P})+(1-\omega) \rho E(\boldsymbol{P})
$$

where $\rho$ is the scaling factor and $\omega$ is the weighting factor.

With the proposed free power sale the total operating cost was reduced to $42.3054 \$$ /day and $33.9223 \mathrm{~kg} /$ day for the emissions after increasing the number of WT and PV, also switching off one of the load comparing to other settings.

Table 3. confirms that the MO optimization technique has made reasonable selections. The selections were not so straightforward; because of the existing the start-stop time limit constraints which have a big effect on the performance of the algorithm. It can be seen that the load was served perfectly.

\begin{tabular}{|c|c|c|c|c|c|c|}
\hline \multicolumn{4}{|c|}{$\begin{array}{l}\text { AVERAGE COST \& } \\
\text { EMISSION }\end{array}$} & \multicolumn{3}{|c|}{$\begin{array}{c}\text { AVERAGE DIFFERENCE WITH RESPECT TO THE } \\
\text { OPTIMAL CASE } \\
\end{array}$} \\
\hline & $\begin{array}{c}\text { COST } \\
(\$ / D A Y) \\
\end{array}$ & $\begin{array}{l}\text { EMISSIONS } \\
\text { (KG/DAY) }\end{array}$ & $\begin{array}{c}\text { COST } \\
(\$ / D A Y) \\
\end{array}$ & $\begin{array}{l}\text { EMISSIONS } \\
\text { (KG/DAY) } \\
\end{array}$ & Cost \% & Emission \% \\
\hline Case A & 99.9283 & 229.4892 & 57.6229 & 195.5672 & $136.2 \%$ & $576.5151 \%$ \\
\hline Case B & 92.6276 & 224.6428 & 25.2862 & 27.3513 & $59.77 \%$ & $80.6292 \%$ \\
\hline Case C & 119.3319 & 8.1371 & 70.3539 & -25.7852 & $166.3 \%$ & $-76.01 \%$ \\
\hline Case D & 54.1359 & 57.7628 & 11.8205 & 24.9295 & $27.94 \%$ & $70.279 \%$ \\
\hline $\operatorname{Ref[10]}$ & 43.3754 & 34.0102 & 1.07 & 0.0879 & $2.5292 \%$ & $0.2637 \%$ \\
\hline $\begin{array}{c}\text { Optimal } \\
\text { Setting }\end{array}$ & 42.3054 & 33.9223 & 00.0000 & 00.0000 & $00.000 \%$ & $00.0000 \%$ \\
\hline
\end{tabular}

Table 3. Saving and emissions reductions of the MG using MOGA.

\section{Conclusion}

This chapter has presented modling and the GA approach to solve the multiobjective problem. From the results obtained, optimization of the above-formulated objective functions using MOGA yields not only a single optimal solution, but a set of Pareto optimal solutions, in which one objective cannot be improved without sacrificing other objectives. For practical applications, however, one solution is needed to be selected, which will satisfy the different goals to some extent. Such a solution is called the best compromise solution. One of the challenging factors of the trade-off decision is the imprecise nature of the decision maker's judgment.

Initially in all the three scenarios, minimum and maximum values of each original objective function are computed in order to obtain the last compromise solution. Minimum values of the objectives are obtained by giving full consideration to one of the objectives and 
neglecting the others. In this study, two objective functions are considered. Operating costs and emission level are optimized individually to obtain minimum values of the objectives. Owing to the conflicting nature of the objectives, emission level has to have maximum values when operating cost is minimum. The GA transforms the original multiobjective optimization problem into a single-objective problem and, thus, the set of noninferior solutions can be easily obtained. Compared with the other strategies of settings, the proposed approach significantly reduces the operating cost and emission level, while satisfying the load demand required by the multiobjective MG problem.

\section{References}

Abido M. A, (2003) A niched Pareto genetic algorithm for Multiobjective environmental/economic dispatch", Electr Power Energy Syst., Vol. 25(2), ., p. 97105.

Abido M. A, (Nov. 2003a) Enverionmental/Economic Power Disparch Using Multiobjective Evolutionary Algorithms, IEEE Trans. on Power Syst, Vol. 18, No. 4 p. 1529 -- 1537.

Azmy, A.M., and Erlich, I., Online Optimal Management of PEM Fuel Cells Using Neural Networks, IEEE Transactions on Power Delivery. Vol. 29, No. 2, p. 1051--1058, Appril 2005.

Barbir, F., and Gomez, T., (Oct. 1996) Efficiency and Economics of Proton Exchange Membrane \{PEM\} Fuel Cell Int. Journal of Hydrogen Energy, Vol. 21, No. 10 p. 891-901.

Campanari, S., and Macchi, E, (July,2004) Technical and Tariff Scenarios effect on Microturbine Trigenerative Applications Journal of Engineering for Gas turbines and Power, Vol.126, p. 581--589.

Chedid, R., and Rahman, S., Unit sizing and control of hybrid wind-solar power systems, IEEE Transactions on Energy Conversion, (1997),Vol. 12, No. 1, pp. 79-85,March 1997.

Chedid, R., and Akiki, H., and Rahman, S.,( March ,1998) A Decision Support Technique For The Design Of Hybrid Solar- Wind Power Systems, IEEE Transaction on Energy Conversion., Vol. 13, No. 1, p.76--83, 1.

Elmusrati, M., Riku, J., and Koivo, N. H, Mutliobjective Distributed Power control Algorithm for CDMA Wireless Commuincation Systems, IEEE Transactions on Vehicular Technology, Vol. 56, NO. 2, , p. 779-788.

Gavanidou,E. S and Bakirtzis, A. G, (March 1992) Design of a Stand Alone System with Renewable Energy Sources using Trade off Methods IEEE Transaction on Energy Conversion, Vol. 7, No. 1 p. 42--48.

Hernandez-Aramburo, C. A., and Green, T. C., and Mugniot, N, (May/June. 2005)“Fuel Consumption Minimization of a Microgrid", IEEE Transactions on Industry Applications, Vol. 41, NO. 3, , p. 673-681.

Huang, C. M., Yang, H. T., and Huang, C. L., (Nov. 1997)Bi-objective power dispatch using fuzzy satisfaction-maximizing decision approach, IEEE Trans. Power Syst., Vol. 12, ., pp. 1715--1721.

Lasnier, F. and Ang, T. G.,( 1990) Photovoltaic Engineering Handbook IOP Publishing Ltd.,1990, ISBN0-85274-311-4\},1990.

Liu, G., Yang, J., and Whidborne J, (March. 2007) Multiobjective optimisation and control, Research Studies Press LTD. 
Manisa Pipattanasomporn., (2004) A Study of Remote Area Internet Access with Embedded Power Generation, Faculty of the Virginia Polytechnic Institute and State University, PhD thesis, \} December 2004.

Mohamed Faisal A, Koivo Heikki, (April 2007) Online Management of MicroGrid with Battery Storage Using Multiobjective Optimization, in Proc. the first International Conference on Power Engineering, Energy and Electrical Drives (POWERENG07), Setubal, Portugal, 12--14.

Mohamed Faisal A, Koivo Heikki, (April, 2009) Environmental/economic power of microgrid using multiobjective optimization", in Proc. The International Conference on Renewable Energies and Power Quality (ICREPQ'09), Valencia, Spain, 15 - 17.

Mohamed Faisal A, Koivo Heikki. (2010), System modelling and online optimal management of MicroGrid using Mesh Adaptive Direct Search, International Journal of Electrical Power \& Energy Systems., Vol. 32,no 5 . , pp. 398-407.

Mohamed Faisal A, Koivo Heikki.,( 2008) Multiobjective Genetic Algorithms for Online Management Problem of Microgrid, Journal of International Review of Electrical Engineering (IREE) Vol. 3,no 1. , pp. 46-54.

Morgantown, W, Emission rates for new DG technologies, the Regulatory Assistance Project., Available,http://www.raponline.org ProjDocs/DREmsRul/Collfile/DGEmissionsMay2001.pdf.

Orero S. O, and Irving M. R, (1997). Large scale unit commitment using a hybrid genetic algorithm, International Journal of Electrical Power \& Energy systems, Vol. 19, No. 1, pp. 45- 55.

Talaq,J. H. El-Hawary, F., and El-Hawary, M. E, (Aug. 1994)A summary of environmental/ economic dispatch algorithms, IEEE Transactions. Power Syst., Vol. 9, , p. 15081516.

Wood, A. J. and Wollenberg, B. F, (1996) Power Generation, Operation and Control, Book., John Wiley $\$ \backslash \& \$$ Sons, Ltd ,New York.

Yinger, R. J. (July 2001) Behaviour of capstone and Honeywell microturbine generators during load changes," Lawrence Berkeley National Laboratory (LBNL-49095) for CERTS,[Online]. Available http://certs.lbl.gov/pdf/LBNL\$\_\$49095.pdf. 


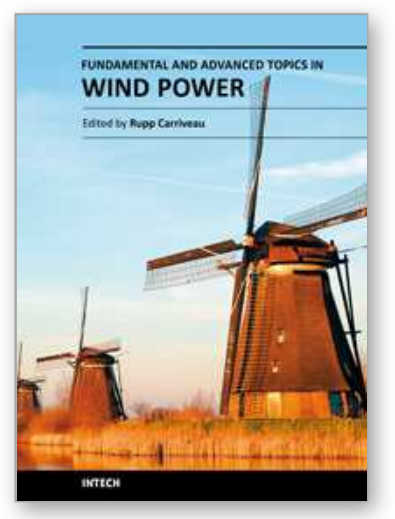

\author{
Fundamental and Advanced Topics in Wind Power \\ Edited by Dr. Rupp Carriveau
}

ISBN 978-953-307-508-2

Hard cover, 422 pages

Publisher InTech

Published online 20, June, 2011

Published in print edition June, 2011

As the fastest growing source of energy in the world, wind has a very important role to play in the global energy mix. This text covers a spectrum of leading edge topics critical to the rapidly evolving wind power industry. The reader is introduced to the fundamentals of wind energy aerodynamics; then essential structural, mechanical, and electrical subjects are discussed. The book is composed of three sections that include the Aerodynamics and Environmental Loading of Wind Turbines, Structural and Electromechanical Elements of Wind Power Conversion, and Wind Turbine Control and System Integration. In addition to the fundamental rudiments illustrated, the reader will be exposed to specialized applied and advanced topics including magnetic suspension bearing systems, structural health monitoring, and the optimized integration of wind power into micro and smart grids.

\title{
How to reference
}

In order to correctly reference this scholarly work, feel free to copy and paste the following:

Faisal A. Mohamed and Heikki N. Koivo (2011). Modelling and Environmental/Economic Power Dispatch of MicroGrid Using MultiObjective Genetic Algorithm Optimization, Fundamental and Advanced Topics in Wind Power, Dr. Rupp Carriveau (Ed.), ISBN: 978-953-307-508-2, InTech, Available from:

http://www.intechopen.com/books/fundamental-and-advanced-topics-in-wind-power/modelling-andenvironmental-economic-power-dispatch-of-microgrid-using-multiobjective-genetic-algori

\section{INTECH}

open science | open minds

\section{InTech Europe}

University Campus STeP Ri

Slavka Krautzeka 83/A

51000 Rijeka, Croatia

Phone: +385 (51) 770447

Fax: +385 (51) 686166

www.intechopen.com

\section{InTech China}

Unit 405, Office Block, Hotel Equatorial Shanghai

No.65, Yan An Road (West), Shanghai, 200040, China

中国上海市延安西路65号上海国际贵都大饭店办公楼 405 单元

Phone: +86-21-62489820

Fax: $+86-21-62489821$ 
(C) 2011 The Author(s). Licensee IntechOpen. This chapter is distributed under the terms of the Creative Commons Attribution-NonCommercialShareAlike-3.0 License, which permits use, distribution and reproduction for non-commercial purposes, provided the original is properly cited and derivative works building on this content are distributed under the same license. 